\title{
Pituitary-thyroid axis in short- and long-term experimental diabetes mellitus
}

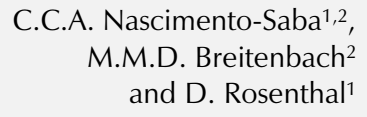

C.C.A. Nascimento-Saba ${ }^{1,2}$, M.M.D. Breitenbach ${ }^{2}$ and D. Rosenthal ${ }^{1}$

\author{
${ }^{1}$ Laboratório de Fisiologia Endócrina, Instituto de Biofísica Carlos Chagas Filho, \\ Centro de Ciências da Saúde, Universidade Federal do Rio de Janeiro, \\ 21491-900 Rio de Janeiro, RJ, Brasil \\ ${ }^{2}$ Departamento de Ciências Fisiológicas, Instituto de Biologia, \\ Universidade do Estado do Rio de Janeiro, 20550-020 Rio de Janeiro, RJ, Brasil
}

\author{
Correspondence \\ D. Rosenthal \\ Laboratório de Fisiologia Endócrina \\ Instituto de Biofísica \\ Carlos Chagas Filho \\ CCS, UFRJ \\ 21949-900 Rio de Janeiro, RJ \\ Brasil. \\ Fax: 55 (021) 280-8193 \\ E-mail: doris@chagas.biof.ufrj.br
}

Research supported by CNPq (No. 530206/93.5), CEPG/UFRJ (SAG 350801P066-0) and FINEP (No. 6.6.92-0009.00).

We dedicate this paper to Prof. Carlos Chagas Filho, founder of the Institute of Biophysics, on the occasion of its 50th anniversary.

Received April 2, 1996 Accepted November 14, 1996

\begin{abstract}
Short-term experimental diabetes mellitus (DM) produces a significant decrease in serum thyroid hormones, a decreased or normal serum thyroid-stimulating hormone (TSH) and a reduction in hepatic and renal $\mathrm{T}_{4}-5^{\prime}$-deiodination. However, little is known about the effects of chronic diabetes mellitus on the pituitary-thyroid axis function. We evaluated the changes induced by very short-term (6 days), short-term (15 days) and chronic (6 months) streptozotocin-induced diabetes mellitus in 3-month old female Dutch-Miranda rat serum $\mathrm{T}_{4}$, serum TSH and $\mathrm{T}_{4}-5$ '-deiodinase activity in the thyroid and pituitary glands. Serum hormones were determined by specific radioimmunoassays. Iodothyronine-5'-deiodinase activities were assayed in the thyroid and pituitary microsomal fractions using $2 \mu \mathrm{M} \mathrm{T}_{4}$ as substrate. Mean serum $\mathrm{T}_{4}$ was significantly decreased from 3.3 to $2.0 \mu \mathrm{g} / \mathrm{dl} 6$ days after diabetes mellitus induction, and from 2.2 to $1.5 \mu \mathrm{g} / \mathrm{dl}$ after 15 days of $\mathrm{DM}$, with no significant changes in serum $\mathrm{TSH}$, indicating a decreased pituitary TSH responsiveness to the diminished suppression by $\mathrm{T}_{4}$, even though pituitary $\mathrm{T}_{4}-5^{\prime}$ '-deiodinase activity was unchanged. Thyroid $\mathrm{T}_{4}-5$ '-deiodinase was unchanged after 6 days of diabetes mellitus, but was significantly increased from 20.6 to $37.0 \mathrm{pmol} \mathrm{T}_{3} / \mathrm{mg}$ protein after 15 days. Six months after diabetes mellitus induction, both serum $\mathrm{T}_{4}$ and thyroid $\mathrm{T}_{4}-5$ '-deiodinase returned to normal ranges and serum TSH was unchanged, although pituitary $\mathrm{T}_{4}-5^{\prime}$ '-deiodinase was now significantly decreased from 2.7 to $1.7 \mathrm{pmol} \mathrm{T}_{3} / \mathrm{mg}$ protein. These findings indicate that some kind of adaptation to chronic insulinopenia may occur at the thyroid level, but this does not seem to be true for the pituitary.
\end{abstract}

\section{Introduction}

There is a well-known relationship between thyroid diseases and diabetes mellitus (DM) in humans and animals. An impaired function of the hypothalamus-pituitary-thyroid axis, including reduced hypothalamic TRH, decreased serum TRH, TSH, $\mathrm{T}_{4}$, and $\mathrm{T}_{3}$ (1-3), low thyroid peroxidase activity (4),
Key words

- Thyroid

- Pituitary

- Diabetes mellitus

- $\mathrm{T}_{4}-5^{\prime}$-deiodinase

- Serum $\mathrm{T}_{4}$

- Serum TSH

- Rat

- Streptozotocin as well as decreased hepatic and renal $\mathrm{T}_{4}-5^{\prime}$ deiodination have been reported in shortterm streptozotocin-induced diabetes mellitus $(3,5,6)$. The hypofunction of the thyroid gland in diabetic animals has generally been ascribed to decreased serum TSH (1-3), although in some studies serum TSH has been found to be normal $(4,5)$. Pituitary $\mathrm{T}_{4}-5^{\prime}$ deiodinase (DI) activity has also been re- 
ported to be either normal or reduced in short-term experimental DM $(3,6)$. However, little is known about the thyroid deiodinase activity or about the effects of chronic diabetes mellitus on thyroid function and $\mathrm{T}_{4^{-}}$ deiodinating activities.

The present study was undertaken in order to compare the effects of short-term and chronic DM on thyroid function and regulation, with special emphasis on thyroid and pituitary $\mathrm{T}_{4}-5$ '-deiodinase activity.

\section{Material and Methods}

Female Dutch-Miranda rats were maintained in a temperature-controlled room (22$25^{\circ} \mathrm{C}$ ) with a light/dark cycle of $12 / 12 \mathrm{~h}$, receiving commercial pellet chow (Purina) and waterad libitum. At the age of 3 months, DM was induced with a single $i p$ injection of streptozotocin (Sigma, St. Louis, MO) dissolved in $0.5 \mathrm{ml} 50 \mathrm{mM}$ citrate buffer, $\mathrm{pH}$ 4.5. The dose of streptozotocin used was 55 $\mathrm{mg} / \mathrm{kg}$ body weight in the very short- and short-term studies (6 and 15 days) and 30 $\mathrm{mg} / \mathrm{kg}$ body weight in the chronic experiments (6 months).

Table 1 - Effect of streptozotocin-induced diabetes on rat body weight variation, gland weights and glycemia.

Diabetes mellitus (DM) was induced by a single ip injection of streptozotocin: 6- and 15-day DM rats received $55 \mathrm{mg}$, and the 6-month DM group received $30 \mathrm{mg}$ of the drug. Results are reported as mean \pm SEM. N, Number of experimental units of 5-6 rats each. $\Delta$ Body weight is the difference between weight at the end of the experimental period and initial body weight. ${ }^{\mathrm{a}} \mathrm{N}=1$.

\begin{tabular}{lrrrrr}
\hline Groups & $N$ & $\begin{array}{c}\Delta \text { Body weight } \\
(\mathrm{g})\end{array}$ & $\begin{array}{c}\text { Thyroid } \\
(\mathrm{mg})\end{array}$ & $\begin{array}{c}\text { Pituitary } \\
(\mathrm{mg})\end{array}$ & $\begin{array}{c}\text { Blood glucose } \\
(\mathrm{mg} / \mathrm{dl})\end{array}$ \\
\hline 6 days & & & & & \\
DM & 8 & -18.2 & $13.4 \pm 1.0$ & $10.8 \pm 1.0$ & $319 \pm 22$ \\
Control & 8 & 4.1 & $13.5 \pm 1.4$ & $10.6 \pm 1.6$ & $120 \pm 5$ \\
& & & & & \\
15 days & & & & & \\
DM & 14 & -21.8 & $11.5 \pm 1.4$ & $9.7 \pm 2.0$ & $328 \pm 11$ \\
Control & 14 & 9.2 & $11.6 \pm 2.1$ & $10.5 \pm 2.6$ & $112^{\mathrm{a}}$ \\
& & & & & \\
6 months & & 13.5 & $11.9 \pm 3.2$ & $10.2 \pm 2.3$ & $290 \pm 34$ \\
DM & 12 & 39.8 & $13.6 \pm 0.9$ & $11.6 \pm 1.3$ & $132 \pm 12$ \\
Control & 7 & & & &
\end{tabular}

Control (C) and diabetic (DM) rats were weighed just before the induction of DM and at the end of each experimental period. Blood glucose levels were determined $48 \mathrm{~h}$ after the streptozotocin injection and at the end of the experimental period using a Dextrostix/ Glucometer (Ames, Elkhart, IN); random glycemia determinations were also performed during the experiment. No insulin was given to any of the diabetic animals.

Six days, 15 days and 6 months after diabetes induction, diabetic and control rats were anesthetized with ether, blood was collected from the jugular vein and glycemia was immediately determined. Thyroid and pituitary glands were rapidly removed, weighed, pooled (5-6 glands per pool), and stored at $-70^{\circ} \mathrm{C}$ for a maximum period of 48 h. Serum was stored at $-20^{\circ} \mathrm{C}$ for $\mathrm{T}_{4}$ and TSH determination by specific radioimmunoassays (RIA). Serum TSH was measured using a kit supplied by NIDDK (National Institute of Diabetes and Digestive and Kidney Diseases, Baltimore, MD) and is reported in terms of the preparation (RP-2) provided with the kit.

\section{5'-Deiodinase activity assay}

Previously described methods (7-10) with minor modifications were used for the determination of thyroid and pituitary DI. Briefly, the pooled thyroid glands were homogenized in $50 \mathrm{mM}$ Tris- $\mathrm{HCl}$ buffer, $\mathrm{pH} 7.4$, containing $250 \mathrm{mM}$ sucrose and $5 \mathrm{mM}$ DTT. The pooled pituitaries were homogenized in 50 $\mathrm{mM}$ Tris- $\mathrm{HCl}$ buffer, $\mathrm{pH}$ 7.6, containing 250 $\mathrm{mM}$ sucrose and $10 \mathrm{mM}$ DTT. The homogenates were centrifuged at $15,000 \mathrm{~g}$ and $4^{\circ} \mathrm{C}$ for $30 \mathrm{~min}$. The supernatant was centrifuged twice at $100,000 \mathrm{~g}$ and $4{ }^{\circ} \mathrm{C}$ for $60 \mathrm{~min}$, and the washed pellet was resuspended in sucrose-free homogenizing buffer. The thyroid microsome fraction was diluted to a protein concentration of $20-50 \mu \mathrm{g} / 100 \mu \mathrm{l}$, and the pituitary microsome fraction to $50-80 \mu \mathrm{g} /$ $100 \mu \mathrm{l}$. Protein concentrations were deter- 
mined by the method of Bradford (11).

The assay mixture contained $100 \mu \mathrm{lmi}-$ crosome fraction and $2 \mu \mathrm{M} \mathrm{T} \mathrm{T}_{4}$ in a final volume of $125 \mu \mathrm{l}$ and was incubated at $37^{\circ} \mathrm{C}$ for $20 \mathrm{~min}$ for the thyroid assay and for 60 $\min$ for the pituitary assay. The reaction was stopped by the addition of $250 \mu \mathrm{l}$ ice-cold $95 \%$ ethanol. The $\mathrm{T}_{3}$ formed was determined in the alcohol extracts by a specific RIA (12) and the results were corrected for extraction efficiency. DI activity is reported as pmol $\mathrm{T}_{3}$ formed per mg microsome fraction protein (pmol $\mathrm{T}_{3} / \mathrm{mg}$ protein).

\section{Statistical analysis}

Results are reported as mean \pm SEM. Serum TSH values were analyzed after logarithmic transformation. Two-way analysis of variance, complemented by multiple comparison tests when appropriate (13), was used for statistical analysis of the data (SuperANOVA program, Abacus Concept, Berkeley, CA).

\section{Results}

The very short- and short-term DM animals had a significant body weight loss during the experimental period, while in the chronic DM rats the body weight gain after 6 months was about one third of that of the controls. On the other hand, the thyroid and pituitary gland weights were not significantly different in any of the DM groups. Plasma glucose levels were significantly increased in all DM groups, being 2-3-fold higher than in the controls. There was no difference in blood glucose levels between the very shortterm, short-term and chronic DM rats, in spite of the different doses of streptozotocin used (Table 1).

No significant changes in serum TSH levels were observed in any of the DM groups, although there was a slight decrease after 6 and 15 days of DM (Figure 1A). Serum $\mathrm{T}_{4}$ was significantly decreased after 6 days $(\mathrm{C}$ :

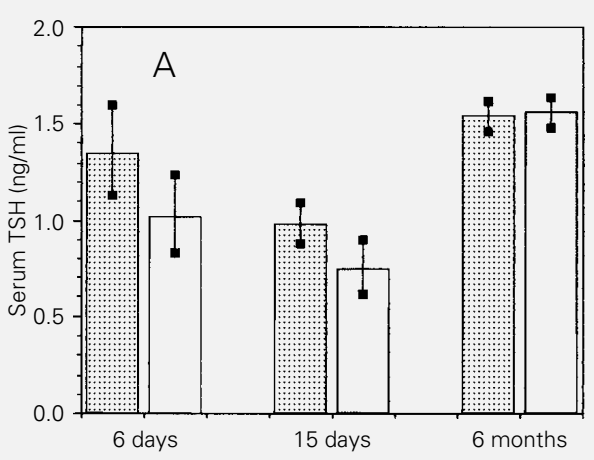

Figure 1 - Effect of very shortterm (6 days), short-term (15 days) and chronic (6 months) streptozotocin-induced diabetes on rat serum TSH $(A)$ and $T_{4}(B)$. Data are reported as mean \pm SEM of control (E) and diabetic rat groups (ם). ${ }^{* *} P<0.01 \mathrm{com}$ pared to respective controls (Student-Newman-Keuls test). Number of experimental groups and doses of streptozotocin used are given in the legend to Table 1.

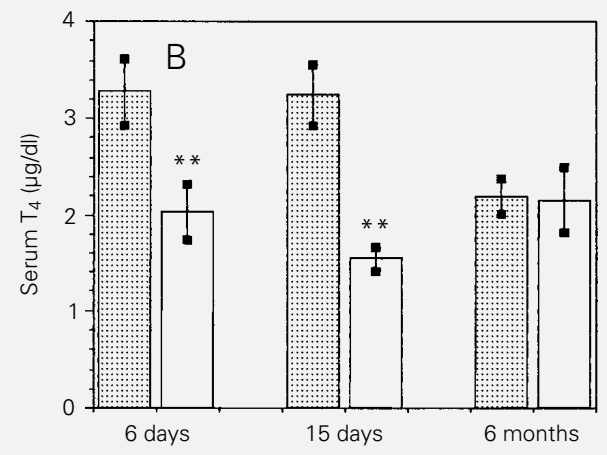

$3.27 \pm 0.34 \mu \mathrm{g} / \mathrm{dl}, \mathrm{DM}: 2.03 \pm 0.29 \mu \mathrm{g} / \mathrm{dl}$, $\mathrm{P}<0.01)$ and 15 days $(\mathrm{C}: 2.24 \pm 0.32 \mu \mathrm{g} / \mathrm{dl}$, DM: $1.53 \pm 0.13 \mu \mathrm{g} / \mathrm{dl}, \mathrm{P}<0.01)$ of $\mathrm{DM}$, but not in chronic DM (C: $2.19 \pm 0.19 \mu \mathrm{g} / \mathrm{dl}$, DM: $2.16 \pm 0.34 \mu \mathrm{g} / \mathrm{dl}$ ) (Figure 1B).

After 6 days of DM induction, neither pituitary DI (C: $1.38 \pm 0.51$; DM: $2.40 \pm 0.74$ $\mathrm{pmol} \mathrm{T}_{3} / \mathrm{mg}$ protein) nor thyroid DI (C: 13.58 \pm 1.05 ; DM: $13.98 \pm 1.71 \mathrm{pmol} \mathrm{T}_{3} / \mathrm{mg}$ protein) was significantly changed (Figure $2 \mathrm{~A}$ and 2B). Pituitary DI remained unchanged after 15 days of DM induction (C: $2.94 \pm$ 0.47; DM: $2.57 \pm 0.50 \mathrm{pmol} \mathrm{T}_{3} / \mathrm{mg}$ protein), whereas thyroid DI was significantly increased (C: $20.58 \pm 3.78$; DM: $37.04 \pm 3.73$ $\mathrm{pmol} \mathrm{T}_{3} / \mathrm{mg}$ protein; $\mathrm{P}<0.01$ ) (Figure $2 \mathrm{~A}$ and 2B). After 6 months of DM, thyroid deiodinase activity was not significantly different compared to the control group $(\mathrm{C}$ : $32.39 \pm 7.01 ; \mathrm{DM}: 23.80 \pm 5.54 \mathrm{pmol} \mathrm{T}_{3} / \mathrm{mg}$ protein) (Figure 2B), whereas pituitary DI was decreased (C: $2.74 \pm 0.90$; DM: $1.71 \pm$ $0.44 \mathrm{pmol} \mathrm{T}_{3} / \mathrm{mg}$ protein, $\mathrm{P}<0.05$ ) (Figure $2 \mathrm{~A})$. 
Figure 2 - Effect of very shortterm (6 days), short-term (15 days) and chronic (6 months) streptozotocin-induced diabetes on rat pituitary $(A)$ and thyroid $(B)$ $\mathrm{T}_{4}-5^{\prime}$-deiodinase (DI) activity. Data are reported as mean \pm SEM of control (E) and diabetic rat groups (ם). ${ }^{*} P<0.05$ and ${ }^{*} \mathrm{P}<0.01$ compared to respective controls (Student-NewmanKeuls test). Number of experimental groups and doses of streptozotocin used are given in the legend to Table 1.
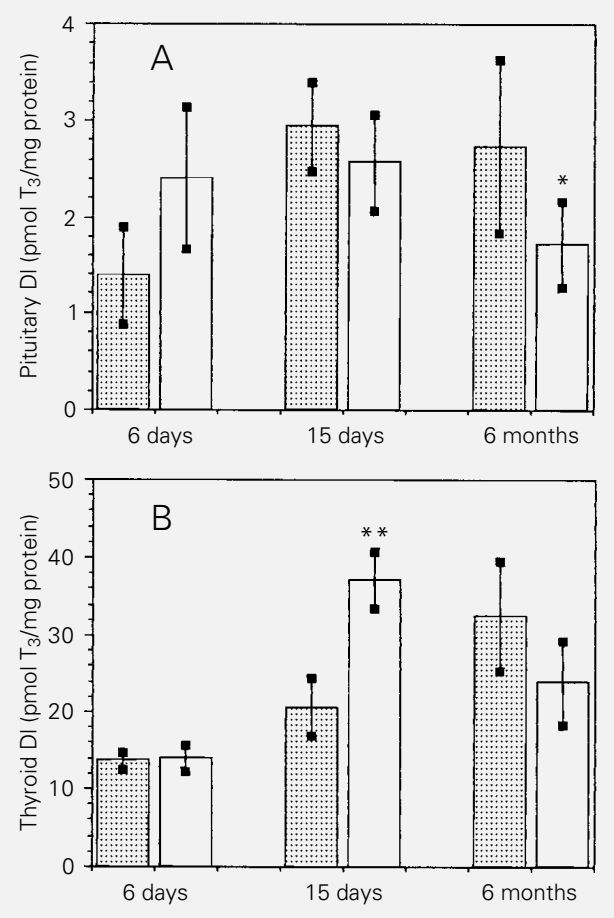

\section{Discussion}

Although the causes of thyroid dysfunction in DM are still unknown, it has been shown that the metabolic alterations caused by DM, or the lack of insulin itself, can directly affect some aspects of thyroid function (14). We used different doses of streptozotocin to induce short- and long-term DM because a longer survival of diabetic rats was only possible when a smaller dose of streptozotocin ( $30 v s 55 \mathrm{mg} / \mathrm{kg}$ body weight) was used. Nevertheless, this lower dose of streptozotocin was effective in inducing DM as shown by the constant fasting hyperglycemia in the chronic DM rats, which did not differ from the DM animals that received a larger streptozotocin dose, and by their marked decrease in body weight gain. The use of small doses of streptozotocin has been thought to induce an unstable diabetic state with large fasting blood glucose variations (15), but in our series the fasting hyperglycemia was relatively constant during the 6-month period, and the chronic diabetic rats had a good survival rate although they never received insulin.

The decrease in body weight after 6 and 15 days of DM was similar to that reported by other investigators studying periods ranging from 5 to 30 days after DM induction $(2,16,17)$. Absolute thyroid and pituitary gland weights were unchanged in all $3 \mathrm{DM}$ groups, in contrast to a significantly decreased thyroid or pituitary gland weight reported previously $(17,18)$ for male Wistar rats 15 days after DM induction. This difference may be related to the different sex or strain of the animals studied.

Several investigators have reported decreased serum TSH as well as $\mathrm{T}_{4}$ levels 10 to 30 days after DM induction $(1-3,17,18)$. The decreased TSH has been ascribed to a diminished pituitary sensitivity to TRH $(17,19)$ or to an intrinsic reduction in the constitutive and/or regulated TSH secretion by the diabetic thyrotropes (20). In the present study, we did not find significant changes in serum TSH of the diabetic rats at any of the times studied. Unaltered levels of serum TSH were also reported in short-term DM by Chopra et al. (5) and Moura et al. (4). After longer periods of DM (4 months), Tontis et al. (21) found serum TSH to be unchanged, although pituitary thyrotropes were markedly increased, suggesting that thyrotrope hyperplasia, compensatory for low thyroid hormone levels, may help to normalize plasma TSH, at least after 4 months of DM. However, it should be kept in mind that 'normal' serum TSH values when serum $\mathrm{T}_{4}$ is decreased, as observed in the short-term DM, indicate some impairment of TSH secretion.

Serum $\mathrm{T}_{4}$ was decreased in the very shortand short-term DM rats, as reported by others $(1-3,5)$, but not in the chronic DM rats. This indicates a change in the factors that determine the decreased $\mathrm{T}_{4}$ secretion during the initial period of insulinopenia. The study of Tontis et al. (21) seems to corroborate this, since the difference in serum $\mathrm{T}_{4}$ between control and DM rats is markedly de- 
creased 8 months after DM induction.

We were unable to determine serum $\mathrm{T}_{3}$ in the present study, but a significant decrease in serum $\mathrm{T}_{3}$ was found after 15 days of DM in a previous study using a similar experimental model (4), and decreased hepatic and renal type I iodothyronine-deiodinase activity in experimental DM has been well documented (5).

The significantly increased thyroid $\mathrm{T}_{4^{-}}$ 5 '-deiodinase activity observed in the 15 day DM rats contrasts with our previous findings of an impaired thyroid peroxidase activity in the same experimental model (4), and shows that the changes produced by short-term insulinopenia cannot be explained by a diminished TSH stimulation of the thyroid gland. In diabetic mice, Bagchi et al. (22) found an increased cyclic AMP production in the thyroid, suggesting an increased sensitivity of the thyroid gland to TSH stimulation. It remains to be seen if a similar hypersensitivity may also be present in the thyroid of the short-term diabetic rat. The $\mathrm{T}_{4}-5^{\prime}$-deiodinase activity was not increased in the chronic DM rats.

Despite the marked decrease in serum $\mathrm{T}_{4}$, total pituitary $\mathrm{T}_{4}-5$ '-deiodinase activity of 6and 15-day DM rats showed no significant changes. Since only the total pituitary 5 'deiodination activity was determined in this study, we are unable to evaluate any specific change in type I or type II iodothyroninedeiodinase activities, which may occur in opposite directions and thus blunt any effect on total $\mathrm{T}_{4}$ deiodination. A fact to be considered is that about $50 \%$ of the anterior pituitary gland is made up of somatotrophs (23). Thus, the pituitary deiodinase activity, as measured by the currently available methods, may not give a true picture of the real thyrotrope deiodinase activity.

After 6 months of DM, the pituitary DI activity was decreased, although serum $\mathrm{T}_{4}$ and TSH and thyroid DI were within normal ranges. A decreased pituitary $\mathrm{T}_{4}$-deiodination in the presence of normal $\mathrm{T}_{4}$ should result in less pituitary $\mathrm{T}_{3}$, and increased TSH secretion. This did not occur, and there was no difference in serum TSH levels between chronic DM and control rats. Thus, either the changes in the whole pituitary gland are not true estimates of thyrotrope deiodinase activity or long-standing diabetes produces some impairment of thyrotrope function.

\section{Acknowledgments}

We would like to thank Drs. Rui M.B. Maciel and Ewaldo M.K. Russo for the generous gift of $\mathrm{T}_{4}$ antibody, and Mr. Advaldo N. Bezerra and Ms. Norma L.A. Faria for excellent technical assistance.

\section{References}

1. Mitsuma T \& Nogimori T (1982). Effects of streptozotocin-induced diabetes mellitus on hypothalamic-pituitary-thyroid axis in rats. Endocrinologica Japonica, 29: 695700.

2. Rondeel JMM, deGreef WJ, Heide R \& Visser TJ (1992). Hypothalamo-hypophysial-thyroid axis in streptozotocin-induced diabetes. Endocrinology, 130: 216-220.

3. van der Elst JPS \& van der Heide D (1992). Effects of streptozotocin-induced diabetes and food restriction on quantities and source of $T_{4}$ and $T_{3}$ in rat tissues. Diabetes, 41: 147-152.
4. Moura EG, Pazos CC \& Rosenthal D (1986). Insulin deficiency impairs thyroid peroxidase activity. A study in experimental diabetes mellitus. In: Medeiros-Neto G \& Gaitan E (Editors), Frontiers in Endocrinology. Plenum Medical Book Co., New York, 627-630.

5. Chopra IJ, Wiersinga W \& Frank H (1981). Alterations in hepatic monodeiodination of iodothyronines in the diabetic rat. Life Sciences, 28: 1765-1776.

6. Ortiz-Caro J, Obregon MJ, Pascual A \& Jolin $T$ (1984). Decreased $T_{4}$ to $T_{3}$ conversion in tissues of streptozotocin-diabetic rats. Acta Endocrinologica, 106: 86-91.
7. Boye N \& Laurberg P (1984). Deiodination of $T_{4}$ to $T_{3}$ and $r T_{3}$ by microsomes from normal human thyroid tissue. Molecular and Cellular Endocrinology, 37: 295-299.

8. Erickson VJ, Cavalieri RR \& Rosenberg LL (1981). Phenolic and nonphenolic ring iodothyronine deiodinases from rat thyroid gland. Endocrinology, 108: 12571264.

9. Ishii $H$, Inada $M$, Tanaka $K$, Mashio $Y$ Naito K, Nishikawa M, Matsuzuka F, Kuma K \& Imura H (1982). Sequential deiodination of thyroxine in human thyroid gland. Journal of Clinical Endocrinology and Metabolism, 55: 890-896. 
10. Kaplan MM (1980). Thyroxine 5'monodeiodination in rat anterior pituitary homogenates. Endocrinology, 106: $567-$ 576.

11. Bradford MM (1976). A rapid and sensitive method for the quantitation of microgram quantities of protein utilizing the principle of protein-dye binding. Analytical Biochemistry, 72: 248-254.

12. Denardin OVP (1986). Influência do diabetes mellitus na conversão periférica de tiroxina $\left(T_{4}\right)$ em 3,5,3'-triiodotironina $\left(T_{3}\right)$ : estudo com perfusão de fígado em ratos. Doctoral thesis, Escola Paulista de Medicina, São Paulo.

13. Zar JH (1974). Biostatistical Analysis. Prentice-Hall, Englewood Cliffs, New Jersey.

14. Povoa LC (1980). Diabetes mellitus e outras endocrinopatias. In: Arduino F (Editor), Diabetes mellitus. Guanabara Koogan, Rio de Janeiro, 183-197.
15. Simon OR \& West ME (1992). Unstable diabetic state produced by a small dose of streptozotocin in rats. West Indian Medical Journal, 42: 146-149.

16. Ferguson DC, Hoenig $M$ \& Jennings AS (1985). Triiodothyronine production by the perfused rat kidney is reduced by diabetes mellitus but not by fasting. Endocrinology, 117: 64-70.

17. Ortiz-Caro J, González C \& Jolin T (1984). Diurnal variations of plasma growth hormone, thyrotropin, thyroxine and triiodothyronine in streptozotocin-diabetic and food-restricted rats. Endocrinology, 115: 2227-2232.

18. González C, Montoya E \& Jolin T (1980). Effect of streptozotocin diabetes on the hypothalamic-pituitary-thyroid axis in the rat. Endocrinology, 107: 2099-2103.
19. Pastor RM \& Jolin T (1983). Peripheral metabolism and secretion rate of thyrotropin in streptozotocin-diabetic rats. Endocrinology, 112: 1454-1459.

20. Bestetti GE, Brandli P \& Rossi GL (1994). Secretory disorders in pituitary thyrotropes of streptozotocin-diabetic male rats. Acta Anatomica, 149: 215-220.

21. Tontis DK, Bestetti GE, Reymond MJ, Lemarchand-Béraud T \& Rossi GL (1990). The age at onset of diabetes influences functional and structural changes in the pituitary-thyroid axis of streptozotocin-diabetic male rats. Virchows Archiv B Cell Pathology, 59: 205-213.

22. Bagchi N, Brown TR, Shivers B, Lucas $S$ \& Mack RE (1981). Decreased thyroidal response to thyrotropin in diabetic mice. Endocrinology, 109: 1428-1432.

23. Thorner MD, Vince ML, Horvarth $\mathrm{E} \&$ Kovacs K (1992). The anterior pituitary. In: Wilson JD \& Foster DW (Editors), Williams' Textbook of Endocrinology. 8th edn. W.B. Saunders, Philadelphia, 221-310. 